\title{
The effect of oxidized low-density lipoprotein combined with adriamycin on the proliferation of Eca-109 cell line
}

Hao $\mathrm{Li}^{{ }^{*+}}$, Qing D Li ${ }^{1+}$, Ping Zhi Wang ${ }^{2+}$, Mei Shu Wang ${ }^{2+}$, Jia Cui ${ }^{3+}$, Tao Yu Diao ${ }^{3}$ and Qing Hui $\mathrm{Li}^{3}$

\begin{abstract}
Background: The purpose of this study was to identify the affect on the proliferation Eca-109 cells treated with oxidized low-density lipoprotein (ox-LDL) combined with adriamycin (ADM).

Methods: Eca-109 cell were cultured in the presence of oxLDL/ADM, and cell proliferation tested by MTT and cell apoptosis was monitored by the proportion of apoptosis and cell cycle by flow cytomester. We simultaneously evaluated the level of associated- apoptosis Bcl-2, Bax, and Caspase-3 gene mRNA and protein.

Results: OxLDL were cytotoxic and activate apoptosis. OxLDL combined with ADM significant enhanced the proportion rate of apoptosis on a time and dose dependency. The expressions of the inhibiting apoptosis $\mathrm{BCl}-2$ gene mRNA and protein were down regulated, whereas, the expressions of the promoting apoptosis Bax, and Caspase-3 genes mRNA and protein were up regulation.

Conclusion: These results suggested that oxLDL have cytotoxicity and activate apoptosis on the Eca-109 cells. OxLDL combined with ADM have a synergistic effect on the apoptosis induced Eca-109 cells. Furthermore, oxLDL may contribute to the improvement of clinical chemotherapy of cancer need to make further investigation.
\end{abstract}

Keywords: Esophagueal squamous cell line, low-density lipoprotein, adriamycin, apoptosis, gene, protein, expression

\section{Background}

Nutrition therapy for patients with terminal cancerassociated cachexia

Weight lost and muscle wasting is a major characteristic of the cachexia associated with diverse pathologies such as terminal cancers, bacterial sepsis, and AIDS [1]. According to recent findings, the progressive weight loss and muscle wasting seen in cancer patients can be halted or even reversed by giving them a high-energy and high-protein supplement containing omega- 3 fatty acids [2]. Various experimental and clinical studies have proved the benefit of consuming a diet supplemented with high-quality proteins (rich in essential amino acids) [3], omega-3 fatty acids [4,5], and antioxidants [6].

\footnotetext{
* Correspondence: haoli2003611@163.com

+ Contributed equally

'Qilu Hospital, Shandong University, Jinan, P.R. China

Full list of author information is available at the end of the article
}

A current study reported that a crayfish enzymatic extract (a diet formulated), which characterized by its high contents in essential amino acids, omega-3 fatty acids and carotenoids, used for the treatment of cancerassociated cachexia in a rat model, and the results showed it can increase the survival of tumor-bearing animals and meliorate the cachexia symptoms - anorexia and body mass loss (muscle and adipose tissue) $[7,8]$. Recently a work reported the result of preoperative nutritional deficiency on mortality after radical cystectomy for bladder cancer ( nutritional deficiency, as measured by preoperative weight loss, body mass index and serum albumin), is a strong predictor of 90-day mortality and poor overall survival [9].

Oxidized low- density lipoprotein (oxLDL) anti- tumor Pathophysiologic effects of oxLDL in atherogenesis have been established. Recent studies show an association with tumorigenesis [10]. Oxidative stress is a term used

\section{Biomed Central}


to denote the imbalance between the concentrations of reactive oxygen (ROS) and nitrogen (RNS) species and the antioxidative defense mechanisms of the body [11]. ROS cause oxidation of lipids, proteins, and DNA in vivo $[12,13]$. LDL is susceptible to oxidation, resulting in the formation of oxLDL $[14,15]$. In recent years, there have been many studies suggesting that excessive lipid peroxidation may play a key role in cancer development [16] Furthermore, it has been found in animal models that a high level of lipid peroxidation is closely associated with carcinogenesis $[17,18]$.

Our previous study showed that oxLDL was decreased in patients with esophageal squamous cell carcinoma (ESCC). The decreasing oxLDL negatively relate to the different stages of the development of esophageal squamous cell carcinoma, which starts from normal epithelium to basal cell hyperplasia, dysplasia or carcinoma in situ and, finally, to invasive ESCC [19-21].

Given the results of these previous studies, we hypothesize that if patients with cancer were given nutrition therapy, especially omega-3 fatty acids, in early stage, the terminal cancer-associated cachexia would delay occurs. The fact prompts us, a composition of lipids, such as oxLDL, may be associated with tumor progression. The aim of the present study was to investigate the role of oxLDL and oxLDL combined with ADM (ADM) in Eca109 cell apoptosis. Through their pro-apoptotic effect observed in vitro, oxLDL would enhance the efficiency of inhibiting the proliferation of cancer cells treated by ADM and thus might be considered as nutritional indicator in the progression of ESCC.

\section{Methods}

\section{Cell culture}

Human ESCC cells, Eca-109, was supplied by the Affiliated Hospital of Tumor Treatment and Prevention of Shandong Academy of Medical Sciences repository and cultured in RPMI1640 medium (Gibco, Los Angeles, CA, USA) supplemented with $10 \%$ heat-inactivated newborn calf serum (HangZhou Sijiqing Biological Engineering Materials Co. Ltd. China), and cells were grown in a humidified incubator at $37^{\circ} \mathrm{Cand} 5 \% \mathrm{CO}_{2}$.

\section{Assay of in vitro oxLDL and ADM sensitivity}

An enzyme-linked immunosorbent assay (ELISA) kits of oxLDL purchased from ADL (Adliteram Diagnostic Laboratories Lnc., USA). The 3-(4, 5-dimethylthiazol-2yl)-2, 5-diphenyltetrazoliumbromide (MTT) assay [22] was tested to calculate the inhibition rate of cell viability treated by drugs. Briefly, the untreated Eca-109 cells were generally in exponential growth phase at the end of the 7-day incubation. All the results represented the average of a minimum of 6 wells. The Eca- $10^{9}$ cells were grown on a 96-well plate at $1 \times 105$ cells $/ \mathrm{ml}$ in complete RPMI 1640 medium.

Oxidized LDL and ADM were added at various different drug concentrations. Eca-109 cells without drugs in medium were used as the blank controls. After the drugs treatment for $20 \mathrm{~h}, 44 \mathrm{~h}$, and $68 \mathrm{~h}$ at $37^{\circ} \mathrm{C}, 20 \mu \mathrm{l}$ MTT were added into each well and incubated for a further $4 \mathrm{~h}$ respectively, then the medium were removed and $150 \mu \mathrm{l}$ dimethyl sulfoxide were added to each well to dissolve the formazan crystals. Absorbance values were measured with spectrophotometer at the wavelength of $570 \mathrm{~nm}$.

The number of cells was also established using a hemocytometer and the cell viability was determined by the trypan blue exclusion test. The inhibition rate of cell viability was calculated using the following formula: Inhibition of cell viability $=(1$-average a value of experimental group/average a value of control group) $\times 100 \%$.

\section{Assay of in vitro oxLDL combined with ADM sensitivity}

Eca-109 cells were treated with $40 \mu \mathrm{g} / \mathrm{ml}$ oxLDL and $0.1 \mu \mathrm{g} / \mathrm{ml}$ ADM for $48 \mathrm{~h}$. Cells were harvested by centrifugation, and then were tested by MTT to calculate the inhibition rate as above description.

\section{Determination of Eca-109 cell Apoptosis Cell apoptosis assay by AnnexinV/PI}

Twenty-four hours, $48 \mathrm{~h}$ and $72 \mathrm{~h}$, after culture, cells were trypsinized, counted $1 \times 10^{6}$ cells per sample were washed twice by ice-cold PBS solution, and then $5 \mu \mathrm{l}$ of annexin V-FITC (AV) and $10 \mu \mathrm{l}$ of propidium iodide (PI) (Sigma) were added to $100 \mu \mathrm{l}$ of cell suspension, followed by incubation for $15 \mathrm{~min}$ at room temperature in the dark. Finally, $400 \mu \mathrm{l}$ of binding buffer was added to each sample, and filtered by 300-mesh nylon net before EPICS XL (Beckman Coulter, Bren CA USA) flow cytometer.EXPO32 ADC Analysis Software was used to analyze the data.

\section{Cell cycle analysis by flow Cytometry}

Twenty-four hours, $48 \mathrm{~h}$ and $72 \mathrm{~h}$, after culture, cells were trypsinized, counted $1 \times 10^{6}$ cells per sample were washed twice by ice-cold PBS solution, and then fixed with $70 \%$ ice-cold ethanol overnight at $4^{\circ} \mathrm{C}$. Fixed cells were washed twice with PBS and fixed with $70 \%$ icecold ethanol overnight at $4^{\circ} \mathrm{C}$. Fixed cells were washed twice with PBS. Cellular DNA was stained with $500 \mu \mathrm{l}$ propidium iodide solution $(0.005 \% \mathrm{PI}, 0.1 \%$ Triton $\mathrm{X}-100$, $0.1 \mathrm{mM}$ EDTA,0.01\%Rnase,0.1 ml PBS), followed by incubation for $30 \mathrm{~min}$ at $4^{\circ} \mathrm{C}$ in the dark, and filtered by 300-mesh nylon net. Samples were analyzed on an EPICS XL flow cytometer (Beckman Coulter, Bren CA USA). The percentage of cells in each phase of the cell cycle was estimated. 


\section{Semiquantitative RT-PCR assay}

In vitro total mRNA was extracted from the cells with Trizol reagent (Invitrogen Co. California, USA) according to manufacturer's instructions. Single stranded cDNA was synthesized by reverse transcription from 1 $\mu \mathrm{g}$ of total RNA using Reverse Transcriptase RNAse MMLV (Invitrogen Co. California, USA) and oligo-dT. The amplification was performed in a final volume of 50 $\mu \mathrm{l}$, containing $5 \mu \mathrm{l} \mathrm{cDNA}, 0.5 \mu \mathrm{l}$ of each oligonucleotide primer, $1 \mu \mathrm{l}$ of each dNTPs, and 1 units of Taq DNA polymerase. Amplification was carried out in a Thermal Cycler. All oligonucleotide primer sets used to measure the expression levels of $\mathrm{Bcl}-1, \mathrm{Bax}, \mathrm{Caspase-3}$ gene mRNA, were previously described $[11,17,23]$. The primers used for measurements of the mRNA expression levels of genes (upstream and downstream, respectively) were CGACGACTTCTCCCGCCGCTACCGC and CCGCATGCTGGGGCCGTACAGTTCC for Bcl-2 mRNA; TCCACCAAGAAGCTGAGCGAG and GTCCA GCCCATGATGGTTCT for Bax mRNA; CCCATTTCT CCATACGCACT and TGACAGCCAGTGAGACTTGG for Caspase-3 mRNA; GTGGGGCGCCCCAGGCACC and CTCCTTAATGTCACGCACGATTTC for $\beta$-actin serves as loading control. Circulating condition: $94^{\circ} \mathrm{C}$ one $\min , 58^{\circ} \mathrm{C}$ one $\min , 72^{\circ} \mathrm{C}$ one min, thirty cycles, then $72^{\circ} \mathrm{C}$ prolong $7 \mathrm{~min}$. End products were identified by electrophoresis using $1.5 \%$ agarose gel.

\section{Western blot analysis}

Cells treated for $48 \mathrm{~h}$ as described above were washed twice in ice-cold PBS and protein extracts of Eca-109 cells were prepared by lysis buffer $(150 \mathrm{mM} \mathrm{NaCl}, 1 \%$ NP-40, 0.5\% 1nM Sodium orthorandate, $0.1 \%$ sodium dodecyl sulfate (SDS), $50 \mathrm{mM}$ Tris $\mathrm{HCl}, 10 \mathrm{mM}$ EDTA, and $1 \mathrm{mM}$ PMSF) for $30 \mathrm{~min}$ at $4^{\circ} \mathrm{C}$. Samples were next centrifuged for $15 \mathrm{~min}$ at $10,000 \mathrm{~g}$. Protein concentrations of supernatants were determined. For each sample, $60 \mu \mathrm{g}$ of protein was loaded on a $12.5 \%$ SDSpolyacrylamide gel, electrophoresed, and transferred to a nitrocellulose membrane (Protran; Schleicher and Schuell, Florham Park, NJ). Each membrane was blocked for $1 \mathrm{~h}$ at room temperature with blocking buffer (TBS containing $0.1 \%$ Tween 20 and 5\% milk powder). Primary antibodies (applied for $1 \mathrm{~h}$ at room temperature, or overnight at $4^{\circ} \mathrm{C}$ ) were: anti-Bcl-2 (Santa Cruz Biotechnology, Inc., Heidelberg, Germany), anti-Bax (Santa Cruz), and anti-actin (mouse monoclonal C-2, Santa Cruz). Antibodies were diluted, thereafter, membranes were incubated for $1 \mathrm{~h}$ with HRPlabeled secondary antibodies (Amersham Pharmacia Biotech, Uppsala, Sweden), goat anti-rabbit, and the blots were finally developed using an ECL Imaging Densitometer (Amersham Bioscience, Buckinghamshire, UK).

\section{Microscopy}

Morphological changes in cancer cells treated with oxLDL and ADM were observed by the trypan blue exclusion test using an Olympus microscope. During the procedure, cell morphology was observed under light microscope for different time.

\section{Statistical Analyses}

Statistical calculations were carried out with the SPSS 15.0 for Windows software package. Results are expressed as the mean \pm standard deviation of independent experiments. Statistical differences between two groups were calculated by the unpaired Student's $t$-test; and the differences among more than two groups were tested by one-way ANOVA or two-way ANOVA, and follow the Bonferroni test for sub- two groups comparison, $P$ values $<0.05$ were considered to be significant.

\section{Results}

OxLDL have cytotoxic effects on Eca 109 cell in vitro

The effect of oxLDL was examined in Eca 109 cell line. OxLDL decreased cell viability and proliferation in a dose- and time- dependent manner in the test (figure 1).

\section{OxLDL induces apoptosis}

The apoptotic frequencies of Eca-109 cells treated with three concentrations $(10,40,90 \mu \mathrm{g} / \mathrm{ml})$ of oxLDL increased in a dose- and time- dependent manner in the flow cytometer test (figure 2).

\section{Assay of in vitro oxLDL combined with ADM sensitivity} Compared with the viability rates of Eca-109 cell treated by oxLDL or ADM alone, the viability rates of Eca-109 cells treated by oxLDL combined with ADM also decreased along with a dose- and time-dependence. The viability rates of Eca-109 cell treated by $40 \mu \mathrm{g} / \mathrm{ml}$ oxLDL combined with $0.5 \mu \mathrm{g} / \mathrm{ml}$ ADM were significantly lower than that in all other groups at $24 \mathrm{~h}, 48 \mathrm{~h}$, and $72 \mathrm{~h}$ after the treatment in the MTT test (figure 3).

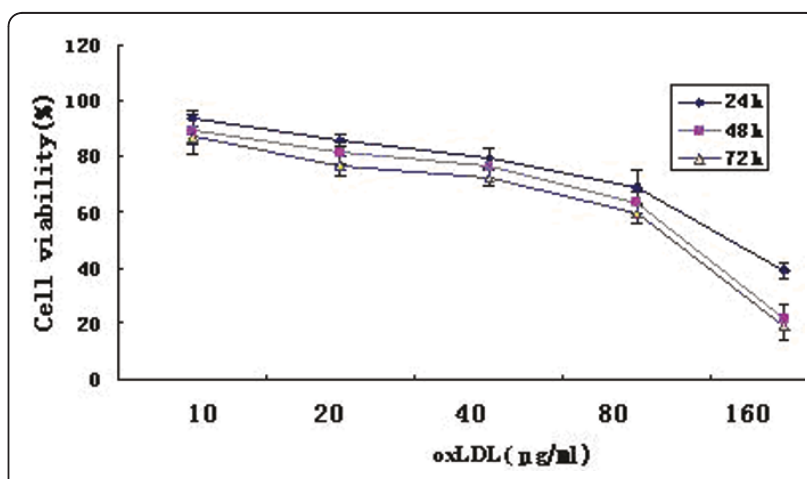

Figure 1 The viability of Eca-109 cells treated with oxLDL in the MTT test. 


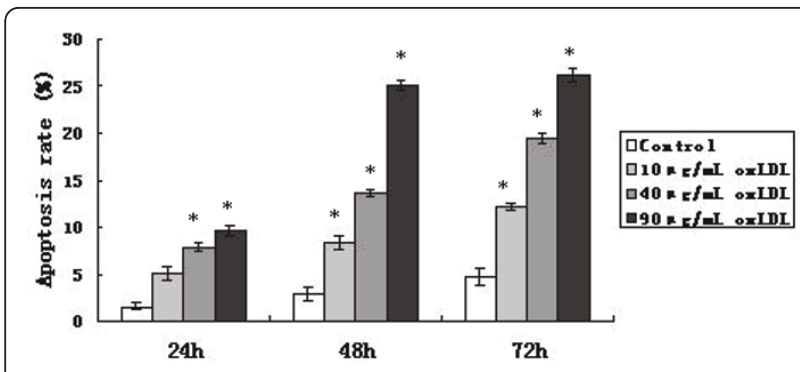

Figure 2 The frequencies of apoptosis for Eca-109 cells treated with three concentration $(10,40,90 \mu \mathrm{g} / \mathrm{ml})$ of oxLDL observed after $24 \mathrm{~h}, \mathbf{4 8} \mathrm{h}$ and $\mathbf{7 2} \mathrm{h}$ of the treatment. *: Compared with the control, $p<0.05$.

\section{Apoptotic morphology}

Typical apoptosis morphological changes were found in Eca-109 cell line $48 \mathrm{~h}$ after treatment with $40 \mu \mathrm{g} / \mathrm{ml}$ oxLDL, $0.1 \mu \mathrm{g} / \mathrm{ml}$ ADM and both of them combined. The changes included nuclear chromatin condensation and fragmentation, plasmic budding, phagocytosis of the extruded and apoptotic body (figure 4).

OxLDL combined with ADM induce the apoptosis and the changes of cell cycle

Compared with the apoptotic frequency of Eca-109 cell treated by $40 \mu \mathrm{g} / \mathrm{ml}$ oxLDL or $0.1 \mu \mathrm{g} / \mathrm{ml}$ ADM alone, the apoptotic rate of Eca-109 cells treated by $40 \mu \mathrm{g} / \mathrm{ml}$ oxLDL combined with $0.1 \mu \mathrm{g} / \mathrm{ml}$ ADM was significantly higher in the flow cytometer test (figure 5).

The abilities of $40 \mu \mathrm{g} / \mathrm{ml}$ oxLDL or $0.1 \mu \mathrm{g} / \mathrm{ml} \mathrm{ADM}$ on alone or their combination to stimulate the Eca-109 cells into the cell cycle were analyzed by flow cytometry. Cells treated with $40 \mu \mathrm{g} / \mathrm{ml}$ oxLDL or $0.1 \mu \mathrm{g} / \mathrm{ml} \mathrm{ADM}$ had substantial increases in the proportion of cells in $S$ phase over time. For example, after treatment with 40 $\mu \mathrm{g} / \mathrm{ml}$ oxLDL, $29.86 \%$ of cells were in S at $48 \mathrm{~h}$. After treatment with $0.1 \mu \mathrm{g} / \mathrm{ml} \mathrm{ADM}, 62.59 \%$ of cells were in $\mathrm{S}$ phase at $48 \mathrm{~h}$. In contrast, after treatment with both of them combination, $75.66 \%$ of cells was in $\mathrm{G} 2 / \mathrm{M}$ blockage at $48 \mathrm{~h}$ (figure 5).

RT-PCR the expression of Bcl-2, Bax and caspase-3 genes Forty eight hours After the Eca-109 cells treated with oxLDL, ADM or their combination, the levels of Bcl-2 gene expression were down-regulated, while the levels of Bax and caspase-3 genes expression were up-regulated, compared with that in the control group (figure 6).

\section{Protein expression of $\mathrm{Bcl}-2$, Bax and caspase- 3 genes in West blot test}

After 48 h of the Eca-109 cells treated with oxLDL, ADM or their combination, the levels of protein expression of Bcl-2 gene decreased, while the levels protein expression of Bax and caspase- 3 genes increased, compared with that in the control group (figure 7 ).

\section{Discussion}

It is well established that lipid-lipoprotein particles among density classes are metabolically processed forming a sequence of diminishing size and lipid distribution, beginning with LPL activity on triglyceride in chylomicron and continuing through HDL, resulting in increasing density and loss of lipid due to enzymic activities during the course of normal lipid transport [24]. Tumor burden also resulted in a marked reduction in adipose tissue, together with a clear hyperlipemia. The loss of fat mass is the result of two altered processes: first, an increase in lipolytic activity, which results in a significant release of both glycerol and fatty acids [25], and second, a marked decrease in the activity of lipoprotein lipase (LPL). This enzyme is responsible for the cleavage of both endogenous and exogenous triacylglycerols to form glycerol and fatty acids, which is reflected as hypertriglyceridemia [26].

Pathophysiologic effects of oxLDL in atherogenesis have been established. Recent studies show a positive

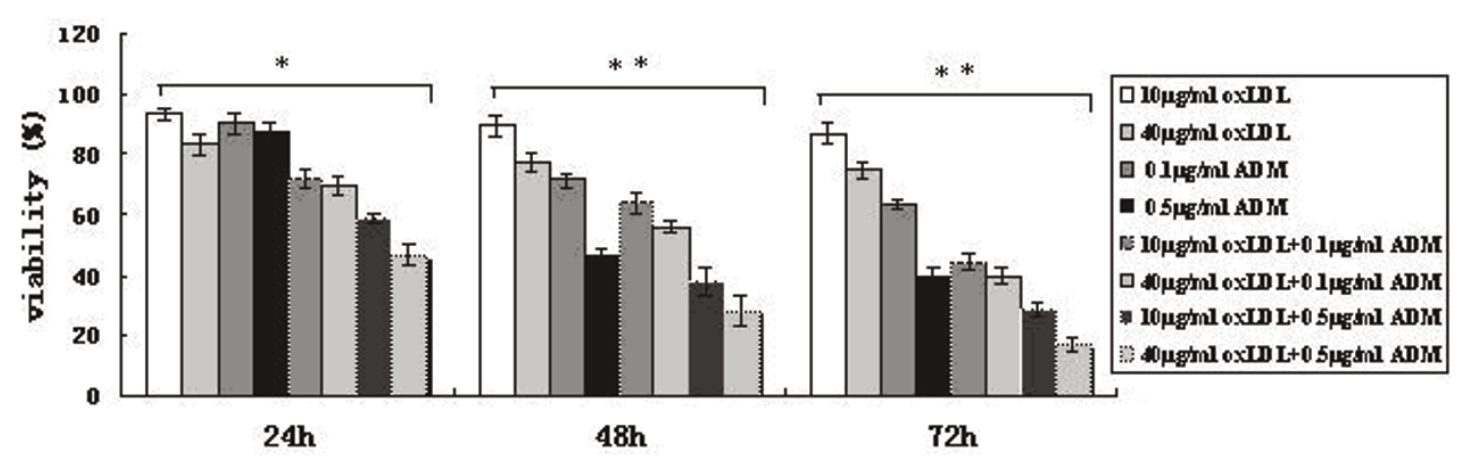

Figure 3 The frequencies of viability for the Eca-109 cell treated with oxLDL, ADM on alone or their combination. ${ }^{*}: p<0.05,{ }^{* *}: p<$ 0.01 in ANOVA test. 


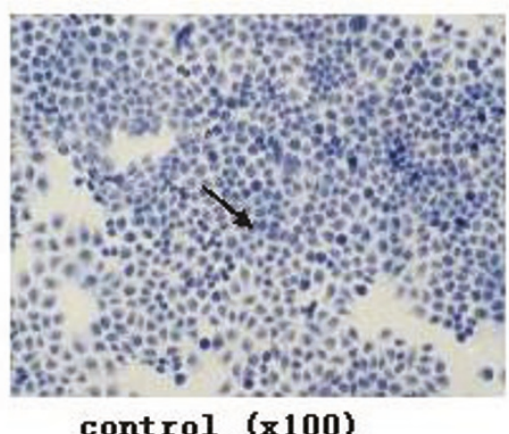

control $(x 100)$

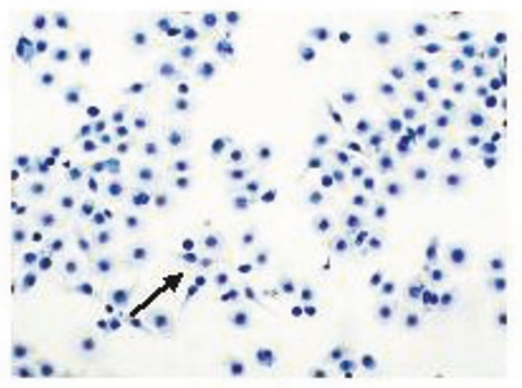

oxLDL (x100)

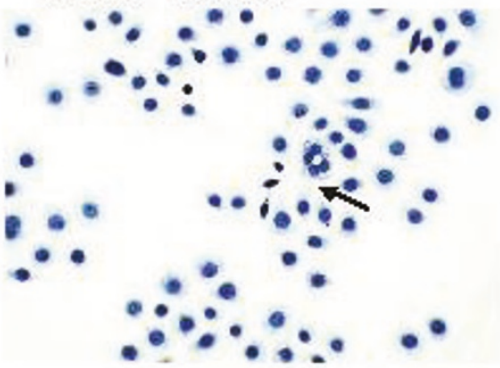

ADI (x100)

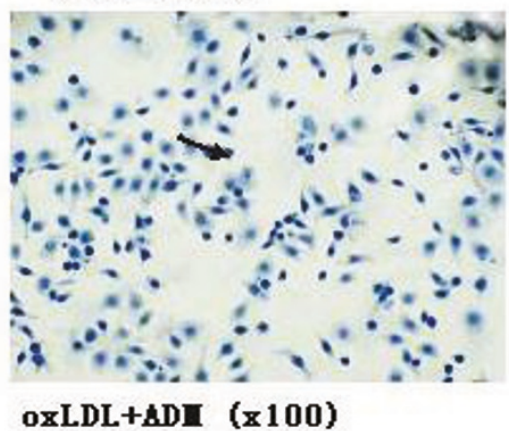

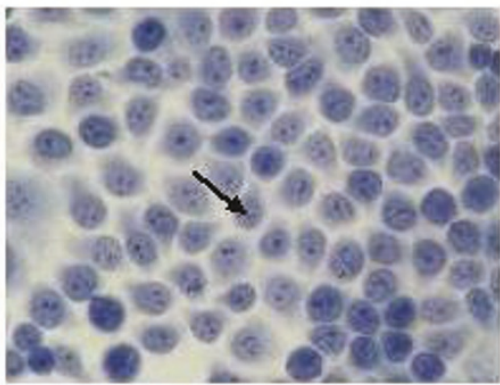

control (x400)

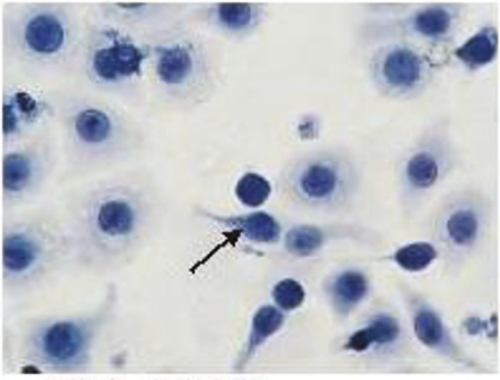

oxLDL ( $\mathrm{x400)}$

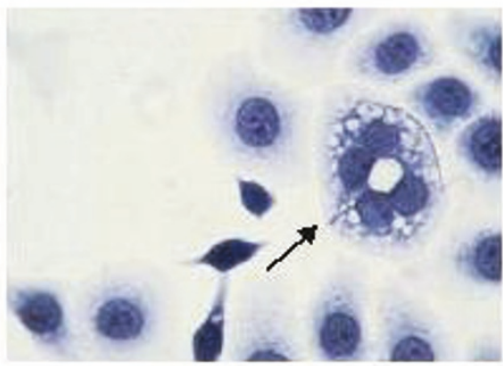

ADI (x400)

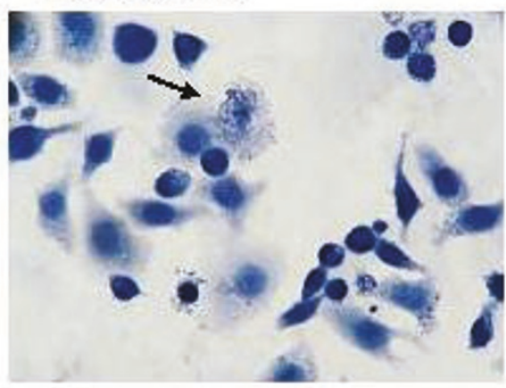

oxLDL+ADI $(x 400)$

Figure 4 Morphology of Eca-109 cell apoptosis in light microscopy (magnification with x100 and x400, respectively for the same slice); When the Eca-109 cell treated with the drugs $48 \mathrm{~h}$ after the treatment, the morphology of the cell showed nuclear chromatin condensation and fragmentation, plasmic budding, phagocytosis of the extruded and apoptotic body. Note: The doses of drugs treated with 40 $\mu \mathrm{g} / \mathrm{ml}$ oxLDL, $0.1 \mu \mathrm{g} / \mathrm{ml} \mathrm{ADM}$, and both of them combined.

correlation between increased serum oxLDL levels and an increased risk of colon, breast and ovarian cancer [27-29]. An earlier study reported that lipids might primarily affect the gonads, and subsequently higher estradiol secretion could influence the development of malignancies in these sites [30]. Later study showed that it is possible that LDL, which is susceptible to oxidation, result in high lipid peroxidation contributing to carcinogenesis [27].

In the past years, there has been a growing body of evidence that excessive lipid peroxidation may play a key role in cancer development [31,32] and in animal model 

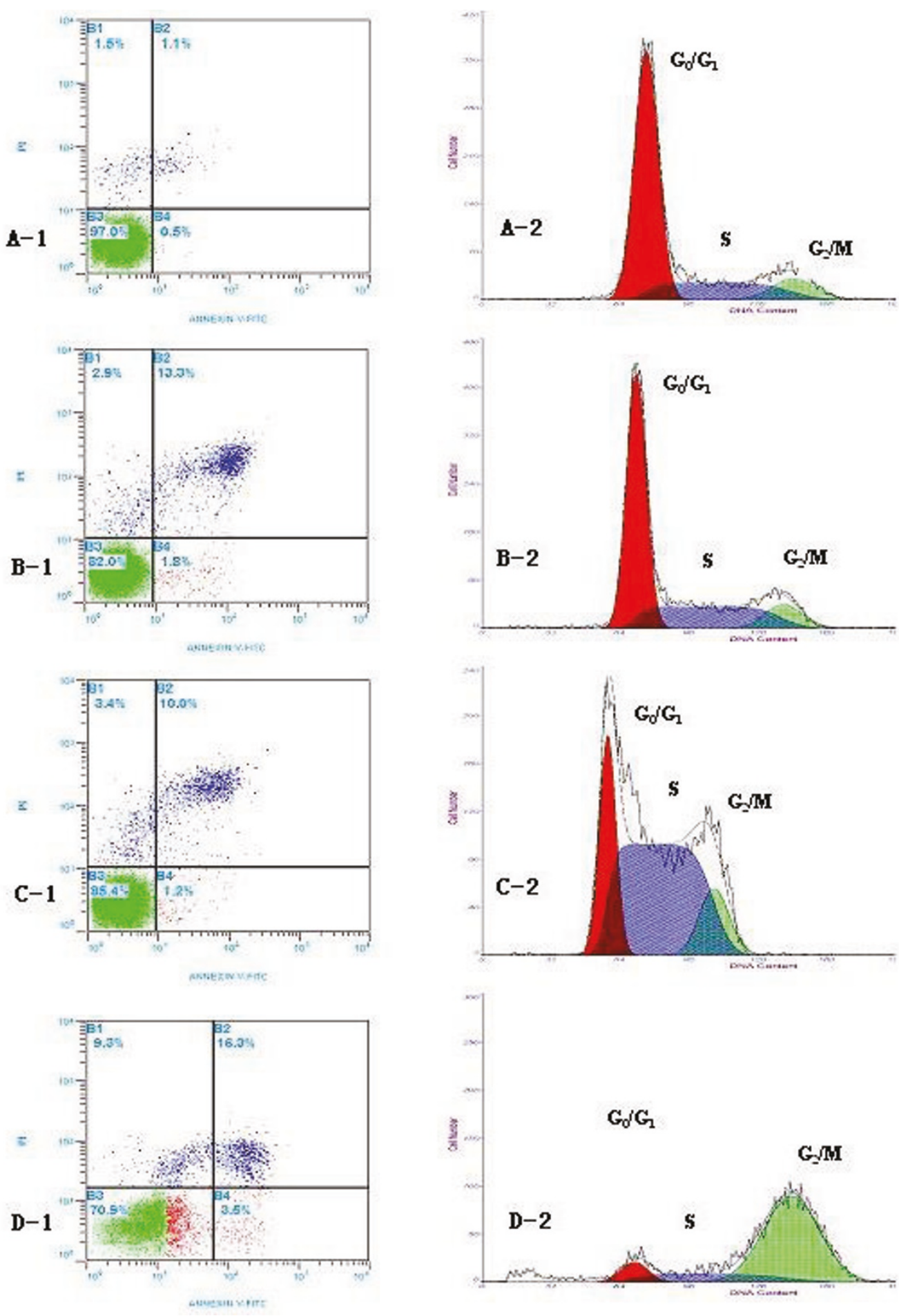

Figure 5 A-1, B-1, C-1 and D-1 showed the distribution of percentages of apoptosis;, and A-2, B-2, C-2 and D-2 showed the distribution of percentages of cell cycle for Eca-109 cells treated with oxLDL or ADM alone and both of them combined after $48 \mathrm{~h}$ of the treatment. For cell cycle: A-2: $67.37 \pm 5.49 \%, 22.03 \pm 0.73 \%$ and $10.60 \pm 0.26 \%$ in the G1/G0, S and G2/M phase of control; B-2: $59.45 \pm$ 4.53\%, $29.86 \pm 1.77 \%$ and $10.69 \pm 0.62 \%$ in the G1/GO, S and G2/M phase of the oxLDL; C-2: $24.12 \pm 3.64 \%, 62.59 \pm 4.29 \%$ and $13.28 \pm 1.45 \%$ in the G1/G0, S and G2/M phase of the ADM; D-2: $8.73 \pm 2.48 \%, 15.61 \pm 5.17 \%$ and $75.66 \pm 3.64 \%$ in the G1/G0, S and G2/M phase of the above oxLDL and ADM combined, respectively. The proportions of apoptosis and phase of cell cycle in $40 \mu \mathrm{g} / \mathrm{ml} \mathrm{oxLDL}+0.1 \mu \mathrm{g} / \mathrm{ml}$ ADM group were significant higher than that in other groups, $\mathrm{p}<0.05$. Dose: A-1 and A-2: control group; B-1 and B-2: $40 \mu \mathrm{g} / \mathrm{ml}$ oxLDL; C-1and C-2: $0.1 \mu \mathrm{g} / \mathrm{ml}$ ADM; D-1 and D-2: $40 \mu \mathrm{g} / \mathrm{ml}$ oxLDL + $0.1 \mu \mathrm{g} / \mathrm{ml} \mathrm{ADM}$. Abbreviation: ADM, adriamycin. 


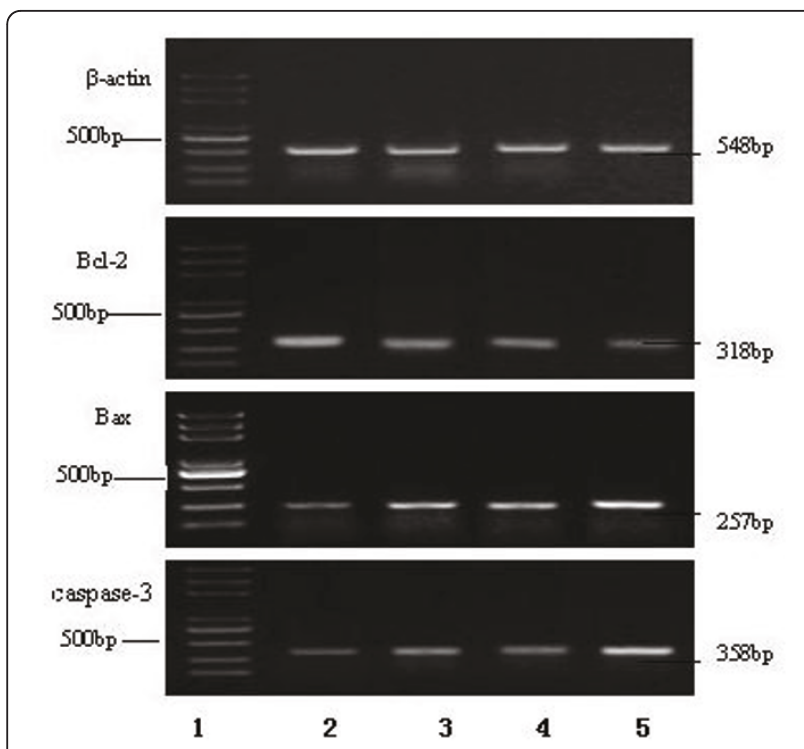

Figure 6 The RT-PCR expression of $\mathrm{Bcl}-2$, Bax and Caspase-3 gene mRNA for the Eca-109 cell treated by the oxLDL, ADM, and both of them combined for $\mathbf{4 8}$ hours. $\beta$-actin serves as loading control. Note: line 1: DNA marker; line 2: control; line 3: 40 $\mu \mathrm{g} / \mathrm{ml}$ oxLDL; line 4: $0.1 \mu \mathrm{g} / \mathrm{ml}$ ADM; Line $5: 40 \mu \mathrm{g} / \mathrm{ml}$ oxLDL + 0.1 $\mu \mathrm{g} / \mathrm{ml}$ ADM. Abbreviation: ADM, adriamycin.

associated with carcinogenesis $[17,33]$. Lipid peroxidation metabolites damage DNA and can seriously inhibit DNA repair capacity through their direct interaction with repair proteins [34]. Circulating oxLDL is also quite reliable biomarker of lipid peroxidation [17]. OxLDL have been reported as a potent independent mitogenic factor [35] that induces proliferation or cell death [36] and furthermore, could contribute to the release of cytokines and growth factors-associated with cancer [37]. However, a

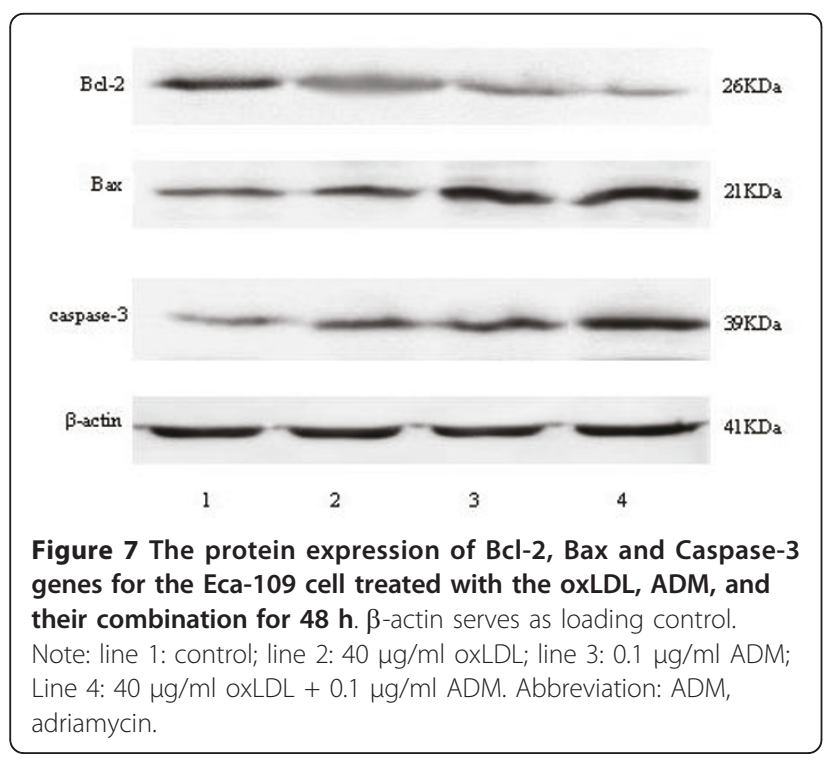

meta-analysis on patients suffering from various diseases revealed that only under severe pathological conditions, e. g. HIV infection, all the indices of oxidative stress correlate with each other [38].

The present investigation, for the first time, identified cytotoxicity on the proliferation of Eca-109 cell line and showed time and dose dependency. The apoptosis of Eca-109 cells treated by oxLDL also showed in time- and dose- manner. The RT-PCR expression of Bcl-2, Bax and caspase- 3 genes mRNA and protein expression of them confirmed the mechanism of the inducing apoptosis by oxLDL. This fact suggests that the physiological amount of oxLDL involves in the process of cell apoptosis, clears the mutation cells or controls the proliferation of cancer cells in vivo. At the advanced stage of cancer, the activity of lipoprotein lipase in vivo decreases, and in consequence, the level of oxLDL declines, promoting an uncontrolled proliferation of tumor cell. Meanwhile, the activity of lipolysis increases, leading to occurrences of the cancer-associated cachexia.

It is confirmed that non-oxidized low-density lipoprotein (nLDL) has no effect on cell lines viability and proliferation [35]. OxLDL with cytotoxicity or autophagy dependences cell types. Under some conditions, oxLDL can be cytotoxic. OxLDL can induce changes in cell cycle protein distribution and expression characteristic of a controlled, adaptive response to a chronic pathological condition. Autophagy is another form of programmed cell death mediated by the lectin-like oxLDL receptor-1 (LOX-1)-dependent [39]. Previous studies showed that oxLDL (more than $10 \mu \mathrm{g} / \mathrm{ml}$ ) has cytotoxic effects on cancer cells in vitro and activate apoptosis and autophagy. OxLDL, applied at physiologic concentrations, decreased cell viability and proliferation in a dose-dependent manner in cell lines tested such as HT29 (colon), OVCAR3 (ovarian), HeLa (cervical), MCF7 (breast), A549 (lung), and PC3 (prostate) [40]. However, when the quiescent human fibroblasts and rabbit smooth muscle cells (VSMC) were treated with oxLDL at physiological ranges $(0,10$, or $50 \mu \mathrm{g} / \mathrm{ml})$ at $24-48 \mathrm{~h}$, the total cell number of them significantly increased [35].

Now in another test, we also observed, the human umbilical vein endothelial cells (HUVEC) was treated with the dose lass than $40 \mu \mathrm{g} / \mathrm{ml}$ oxLDL at physiological ranges for 24-48 h. The resulted in significant increases in total HVEC cell counts at both time points. However, when the cell treated with larger than $40 \mu \mathrm{g} / \mathrm{ml}$ oxLDL, the inhibiting proliferation phenomenon observed at the same time points for the cells (data not shown).

More than two decades ago, epidemiological studies showed a U-shaped relationship between total cholesterol (TC) levels and risk of all-cause mortality. The relationship between the baseline serum cholesterol level to total mortality was attributed to the high 
number of deaths associated with serum cholesterol level at the high end of the distribution (mainly due to coronary heart disease) and at the low end (mainly due to cancer) [41-43]. Recent study reported that in atherosclerosis, ox-LDL linkage with its receptor LOX-1 activates the inflammatory pathway through NF- $\kappa \mathrm{B}$, leading to cell transformation. LOX-1 is important for maintaining the transformed state in developmentally diverse cancer cell lines and for tumor growth, suggesting a molecular connection between atherogenesis and tumorigenesis [10]. One study reported that low dose oxLDL has bilateral adjustment characteristics on the proliferation of quiescent human fibroblasts and rabbit smooth muscle cells. Western blot analysis revealed that oxLDLstimulated cell proliferation was associated with significant increases in the expression of proteins that regulate entry into and progression through the cell cycle. Surprisingly, the expression of cell cycle inhibitors (p21 and p27) was stimulated by oxLDL as well, but this was to a lesser extent than the effects on cell cycle-activating proteins [36]. In the present study, we also found, the Eca-109 cells were treated with more than $40 \mu \mathrm{g} / \mathrm{ml}$ oxLDL the cytotoxicity of it was significantly increase on a time- and dose- dependency. It is possible that the levels of oxLDL in vivo are dynamical changes based on the body's conditions. Under some condition, oxLDL can be cytotoxic.

One clinical study indicated that the levels of oxLDL were increased among both breast and ovarian cancer patients as compared to the control subjects [44]. Another previous study showed that fasting lipid and lipoprotein studies on 38 consecutively diagnosed children with acute lymphoblastic leukemia (ALL). The results showed that the level of LDL decreased in the process of chemotherapy of the malignant tumor and recovered to normal level after the treatment. For those patients with ALL who had a long-term survival, the normal levels of LDL also were important [45]. The effects of tamoxifen treated the patients with breast cancer showed that LDL particle diameter correlated negatively with plasma triglyceride (TG) $(\mathrm{r}=-0.62 ; \mathrm{p}<0.001)$. Tamoxifen-induced fatty liver in breast cancer patients may be atherogenic, via increased TG and consequent small, easily oxidized LDL particles [46]. The smaller diameter of LDL particles, the more easily oxidized into oxLDL.

Recent review the results of cancer-related malnutrition patients with and without nutritional supplements showed the weight loss is multifactorial but can be generally separated into two components. One component included those outcomes that are the result of the metabolic abnormalities as a direct consequence of the tumor, and a second component including results of treatments, psychological issues, and others. For people with cancer the implement nutrition interventions are effective, but there is no clarity in best options for nutrition management [47]. More clinical observation of the dynamic changes of oxLDL for other type cancer in chemotherapy need to be confirm in future.

Another major finding of the present study is a synergistic effect on inducing apoptosis of Eca-109 cells treated by the combination of $40 \mu \mathrm{g} / \mathrm{ml}$ oxLDL and $0.1 \mu \mathrm{g} /$ $\mathrm{ml}$ ADM. The proportion rate of apoptosis ECA-109 cells treated with their combination significantly increased $(19.79 \pm 1.32)$, compared with that $40 \mu \mathrm{g} / \mathrm{ml}$ oxLDL $(15.11 \pm 0.61), 0.1 \mu \mathrm{g} / \mathrm{ml} \mathrm{ADM}(11.27 \pm 0.54)$. As well known, the chemical-therapy drugs of cancer, such as ADM, have toxicity, if oxLDL combined with the cytotoxic drugs could use in the clinic, may be more benefit for the patient's therapy. Further studies are required in order to elucidate whether oxLDL play a causative or merely consequential role in cancer process and to designate a novel approach in the combination therapeutic strategies.

\section{Conclusion}

These results suggested that oxLDL have cytotoxicity on the proliferation of Eca-109 cell line and showed time and dose dependency. OxLDL combined with ADM have a synergistic effect on the apoptosis induced Eca109 cells. Furthermore, oxLDL may contribute to the improvement of clinical chemotherapy of cancer need to make further investigation.

\section{Abbreviations}

oxLDL: oxidized low- density lipoprotein; ELISA: enzyme-linked immunosorbent assay; MTT: 3-(4, 5-dimethylthiazol-2-yl)-2, 5diphenyltetrazoliumbromide; ESCC: esophageal squamous cell carcinoma; ADM: adriamycin.

\section{Acknowledgements}

This study was supported by the Project of National Natural Science Foundation of China (No.30571601 and No.30600258) and the 2006 Doctor Fund Projects of Shandong Province, China (No. 2006BS03061).

\section{Author details}

${ }^{1}$ Qilu Hospital, Shandong University, Jinan, P.R. China. ${ }^{2}$ College of Public Health, Shandong University, Jinan, P.R. China. ${ }^{3}$ Institutes of Basic Medicine, Shandong Academy of Medical Sciences Jinan, P.R. China.

\section{Authors' contributions}

Members listed below made their respective contributions to this manuscript. Professor HL, QDL, PZW, MSW and JC designed the skeleton of this study, performed cell proliferation and apoptosis, expression of gene and protein and drafted the manuscript (they made the same contribution to this work). TYD and QHL carried out the data analysis and checked the manuscript. All authors read and approved the final manuscript.

\section{Competing interests}

The authors declare that they have no competing interests.

Received: 12 May 2011 Accepted: 29 June 2011 Published: 29 June 2011

\section{References}

1. Cohen J, Lefor AT: Nutrition support and cancer. Nutrition 2001, 17:698-699. 
2. Silver S: EPA halts cancer-induced weight loss. Lancet Oncol 2000, 3:7.

3. May PE, Barber A, D'Olimpio JT: Reversal of cancer related wasting using oral supplementation with a combination of beta-hydroxybetamethylbutyrate, arginine, and glutamine. Am J Surg 2002, 183:471-479.

4. Barber MD, Fearon $\mathrm{KCH}$, Ross JA: Eicosapentaenoic acid modulates the immune response but has no effect on a mimic of antigen-specific responses. Nutrition 2005, 21:588-593.

5. Burns CP, Halabi S, Clamon GH: Phase I clinical study of fish oil fatty acid capsules for patients with cancer cachexia: cancer and leukemia group B study 9473. Clin Cancer Res 1999, 5:3942-3947.

6. Comi D, Baronzio GF, Vecchio C, Zambelli A, Cargnel A, Ferrario R, Galante F, Barlocco A, Pravettoni G: Oxygen radicals, antioxidant vitamins and minerals in AIDS cachexia. Nutrition 1997, 13:272.

7. Cremades O, Parrado J, Jover M, de Tera'n LC, Gutie'rrez JF, Palomas JDB: Nutritional treatment of cancer cachexia in rats -Use of a diet formulated with a crayfish enzymatic extract. Eur J Nutr 2007, 46:347-353.

8. Capra S, Bauer J, Davidson W, Ash S: Nutritional therapy for cancerinduced weight loss. Nutr Clin Pract 2002, 17:210-2213.

9. Gregg JR, Cookson MS, Phillips S, Salem S, Chang SS, Clark PE, Davis R, Stimson CJ, Aghazadeh JM, Smith JA, Barocas DA: Effect of Preoperative Nutritional Deficiency on Mortality After Radical Cystectomy for Bladder Cancer. J Urology 2011, 185:90-96.

10. Lu J, Mitra S, Wang X, Khaidakov M, Mehta JL: Contribution of Oxidative Stress and Lectin-like OxLDL-receptor LOX-1 in Atherogenesis and Tumorigenesis. Antioxid Redox Signal 2011.

11. Dotan Y, Lichtenberg D, Pinchuck I: Lipid peroxidation cannot be used as a universal criterion of oxidative stress. Prog Lipid Res 2004, 43:200-227.

12. Saintot M, Astre C, Pujol H, Gerber M: Tumor progression and oxidantantioxidant status. Carcinogenesis 1996, 17(6):1267-1271.

13. Guyton KZ, Kensler TW: Oxidative mechanisms in carcinogenesis. Br Med Bull 1993, 49:523-544.

14. Ray G, Husain SA: Role of lipids, lipoproteins and vitamins in women with breast cancer. Clin Biochem 2001, 34:71-76.

15. Ray G, Batra S, Shukla NK, Deo S, Raina V, Ashor S, Husain SA: Lipid peroxidation, free radical, and antioxidant status in breast cancer. Breast Cancer Res Treat 2000, 59:163-170.

16. Uchida K: 4-hydroxy-2-nonenal: a product and mediator of oxidative stress. Prog Lipid Res 2003, 42:318-343.

17. Chung FL, Nath RG, Ocando J, Nishikawa A, Zhang L: Deoxyguanosine adducts of t-4-hydroxy-2-nonenal are endogenous DNA lesions in rodents and humans: detection and potential sources. Cancer Res 2000, 60:1507-1511.

18. Sonoda I, Imoto I, Inoue J, Shibata T, Shimada Y, Chin K, Imamura M, Amagasa T, Gray JW, Hirohashi S, Inazawa J: Frequent silencing of low density lipoprotein receptor-related protein 1B (LRP1B) expression by genetic and epigenetic mechanisms in esophageal squamous cell carcinoma. Cancer Res 2004, 64:3741-3747.

19. Yang YF, Li H, Xu XQ, Diao YT, Fang XF, Wang Y, Zhao DL, Wu K, Li HQ: An expression of squamous cell carcinoma antigen 2 in peripheral blood within the different stages of esophageal carcinogenesis. Dis Esophagus 2008, 21:395-401.

20. Wang Yan, Li Hao, Diao Yutao, Li Hui-qing, Zhang Yukun, Yin Chang, Cui Yongchun, Ma Qing, Fang Xuegiang, Zhou Yingzhi, Yang Yanfang: Relationship between oxidized LDL antibodies and different stages of esophageal carcinogenic progressionAcknowledgements. Archives of Medical Research 2008, 39:760-767.

21. Diao YT, Li H, Li HQ, Zhou YZ, Ma Q, Wang Y, Li D: Association of serum levels of lipid and its novel constituents with the different stages of esophageal carcinoma. Lipids in Health and Disease 2009, 8:48-50.

22. Hida T, Ueda R, Takahashi T, Watanabe H, Kato T, Suyama M, Sugiura T, Ariyoshi Y, Takahashi T: Chemosensitivity and radiosensitivity of small cell lung cancer cell lines studied by a newly developed 3-(4,5dimethylthiazol-2-yl)-2,5-diphenyltetrazolium bromide (MTT) hybrid assay. Cancer Res 1989, 49:4785-4790.

23. Manoharan S, Kolanjiappan K, Kayalvizhi M: Enhanced lipidperoxidation and impaired enzymic antioxidant activities in theerythrocytes of patients with cervical carcinoma. Cell Mol Biol Lett 2004, 9:699-707.

24. Warnick GR, Knopp RH, Fitzpatrick V, Branson L: Estimating low-density lipoprotein cholesterol by the Friedewald equation is adequate for classifying patients on the basis of nationally recommended cutpoints. Clin Chem 1990, 36:15-9.

25. Argile's JM, A 'Ivarez B, Lo'pez-Soriano FJ: The metabolic basis of cancer cachexia. Med Res Rev 1997, 175:477-498.

26. Fried SK, Zechner R: Cachectin/tumor necrosis factor decreases human adipose tissue lipoprotein lipase mRNA levels, synthesis, and activity. $J$ Lipid Res 1989, 30:1917-1923.

27. Delimaris I, Faviou E, Antonakos G, Stathopoulou E, Zachari A, DionyssiouAsteriou A: Oxidized LDL, serum oxidizability and serum lipid levels in patients with breast or ovarian cancer. Clin Biochem 2007, 40:1129-1134.

28. Suzuki K, Ito Y, Wakai K, Kawado M, Hashimoto S, Toyoshima H, Kojima M, Tokudome S, Hayakawa N, Watanabe Y, Tamakoshi K, Suzuki S, Ozasa K, Tamakoshi A, Japan Collaborative Cohort Study Group: Serum oxidized low-density lipoprotein levels and risk of colorectal cancer: A casecontrol study nested in the Japan collaborative cohort study. Cancer Epidemiol Biomarkers Prev 2004, 13:1781-1787.

29. Mueller E, Smith M, Sarraf P, Kroll T, Aiyer A, Kaufman DS, Oh W, Demetri G, Figg WD, Zhou XP, Eng C, Spiegelman BM, Kantoff PW: Effects of ligand activation of peroxisome proliferator- activated receptor gamma in human prostate cancer. Proc.Natl Acad Sci USA 2000, 97:10990-10995.

30. Stepsenwol J: Carcinogenic effect of cholesterol in mice. Proc Soc Exp Biol Med 1966, 121:168-171.

31. Guyton KZ, Kensler TW: Oxidative mechanisms in carcinogenesis. Br Med Bull 1993, 49:481-483.

32. Uchida K: 4-hydroxy-2-nonenal: a product and mediator of oxidative stress. Prog Lipid Res 2003, 42:318-343.

33. Sanchez-Perez Y, Carrasco-Legleu C, Garcia-Cuellar C, Perez-Carreon J, Hernandez-Garcia S, Salcido-Neyoy M, Alemán-Lazarini L, Villa-Treviño S: Oxidative stress in carcinogenesis. Correlation between lipid peroxidation and induction of preneoplastic lesions in rat hepatocarcinogenesis. Cancer Lett 2005, 217:25-32.

34. Wiseman $\mathrm{H}$, Halliwell B: Damage to DNA by reactive oxygen and nitrogen species; role in inflammatory disease and progression to cancer. Biochem J 1996, 313:17-19.

35. Zettler ME, Prociuk MA, Austria JA, Massaeli H, Zhong G, Pierce GN: oxLDL stimulates cell proliferation through a general induction of cell cycle proteins. J Am Physiol Heart Circ Physiol 2003, 284:H644-53.

36. Han CY, Pak YK: Oxidation-dependent effects of oxidized LDL proliferation or cell death. Exp Mol Med 1999, 31:165-73.

37. Motta M, Pistone G, Franzone AM, Romeo MA, Di Mauro S, Giugno L, Ruello P, Malaguarnera M: Antibodies against ox-LDL serum levels in patients with hepatocellular carcinoma. Panminerva Med 2003, 45:69-73.

38. Kontush A, Spranger T, Reich A, Djahansouzi S, Karten B, Braesen JH, Finckh B, Kohlschütter A, Beisiegel U: Whole plasma oxidation assay as a measure of lipoprotein oxidizability. Biofactors 1997, 6:99-109.

39. Scoles DR, Xu X, Wang H, Tran H, Taylor-Harding B, Li A, Karlan BY: Liver X receptor agonist inhibits proliferation of ovarian carcinoma cells stimulated by oxidized low density lipoprotein. Gynecol Oncol 2010, 116:109-116

40. Zabirnyk O, Liu W, Khalil S, Sharma A, Phang JM: Oxidized low-density lipoproteins upregulate praline oxidase to initiate ROS-dependent autophagy. Carcinogenesis 2010, 31:446-454.

41. Ginter E: Blood cholesterol levels and mortality in cancer. Bratis/ Lek Listy 1990, 91:70-76

42. Tamakoshi A, Ohno Y, Suzuki S, Kawamura T, Wakai K, Nakamura R: Epidemiological remarks on low serum cholesterol level and cancer risk of all sites. Nippon Koshu Eisei Zasshi 1994, 41:393-403.

43. Karvonen J, Päivänsalo $M$, Kesäniemi YA, Hörkkö S: Circulation Immunoglobulin M type of autoantibodies to oxidized low-density lipoprotein has an inverse relation to carotid artery atherosclerosis. Circulation 2003, 108:2107-2112.

44. Delimaris I, Faviou E, Antonakos G, Stathopoulou E, Zachari A, DionyssiouAsteriou A: Oxidized LDL, serum oxidizability and serum lipid levels in patients with breast or ovarian cancer. Clin Biochem 2007, 40:1129-1134.

45. Parsons SK, Skapek SX, Neufeld EJ, Kuhlman C, Young ML, Donnelly M, Brunzell JD, Otvos JD, Sallan SE, Rifai N: Asparaginase-associated lipid abnormalities in children with acute lymphoblastic leukemia. Blood 1997, 89(6):1886-1895

46. Wakatsuki A, Ogawa Y, Saibara T, Okatani Y, Fukaya T: Size and oxidative susceptibility of low-density lipoprotein particles in breast cancer 
patients with tamoxifen-induced fatty liver. J Clin Endocrinol Metab 2002,

87:3676-3681

47. Capra Sandra, Bauer Judith, Davidson Wendy, Susan Ash: Nutritional Therapy for Cancer-Induced Weight Loss. Nutrition in Clinical Practice 2002, 17:210-213.

doi:10.1186/1476-511X-10-108

Cite this article as: Li et al:: The effect of oxidized low-density

lipoprotein combined with adriamycin on the proliferation of Eca-109 cell line. Lipids in Health and Disease 2011 10:108.

Submit your next manuscript to BioMed Central and take full advantage of:

- Convenient online submission

- Thorough peer review

- No space constraints or color figure charges

- Immediate publication on acceptance

- Inclusion in PubMed, CAS, Scopus and Google Scholar

- Research which is freely available for redistribution 
Li et al. Lipids in Health and Disease 2011, 10:108

Page 11 of 11

http://www.lipidworld.com/content/10/1/108 